\title{
Cost of Adding E85 Fueling Capability to Existing Gasoline Stations: NREL Survey and Literature Search
}

The cost of purchasing and installing E85 fueling equipment varies widely, yet station owners need to have an idea of what to expect when budgeting or reviewing bids for this upgrade. The purpose of this document is to provide a framework for station owners to assess what a reasonable cost would be. This framework was developed by the National Renewable Energy Laboratory (NREL) by surveying actual costs for stations, conducting a literature search, noting the major cost-affecting variables, addressing anomalies in the survey, and projecting changes in future costs.

The findings of NREL's survey and literature search are shown in the table below. This table divides the study's findings into two categories: stations that installed new E85 storage tanks and stations that converted existing fuel tanks to store E85.

\section{NREL Survey}

NREL's survey includes the costs incurred for 120 E85 stations -84 new tank installations and 36 existing tank conversions. Data was provided through invoices and cost estimates by grant administrators, station owners, and project managers. The range of these costs was expansive: $\$ 7,559$ to $\$ 247,600$ for a new tank and $\$ 1,736$ to $\$ 68,000$ for an existing tank. The mean for the existing tank scenario was much higher than the median, indicating that the mean was raised by a smaller number of expensive conversions.

\section{Literature Search}

The literature search largely supports the findings of NREL's survey. However, there are three instances when the literature doesn't encompass the survey results. They are:

- When the new tank mean is $\$ 1,735$ above the range estimated by the U.S. Department of Transportation (DOT), the U.S. Environmental Protection Agency (EPA), and the U.S. Department of Energy (DOE).

- When the new tank mean is $\$ 9,328$ above the range estimated by Downstream Alternatives Inc. (DAI).

- When the existing tank median is $\$ 7,763$ below the range estimated by DAI.

\section{Major Variables Affecting Costs}

NREL discerned some of the major variables affecting costs by reviewing itemized invoices and interviewing station owners, project managers, and grant administrators. The most influential variables are:

- Dispenser needs. Some stations need multiple new multiproduct dispensers to dispense E85, while others just need to convert one dispenser to make it compatible with E85.

- Excavation and concrete work. New tank installation costs largely depend on the amount of excavation required and

\section{Costs of Adding E85 Equipment to Existing Gasoline Stations}

\begin{tabular}{|c|c|c|c|c|}
\hline Scenario & Cost & Source* & Description & Major Variables Affecting Cost \\
\hline \multirow{5}{*}{$\begin{array}{l}\text { New tank, } \\
\text { new or retrofit } \\
\text { dispenser(s) }\end{array}$} & $\begin{array}{l}\text { Mean: } \$ 71,735 \\
\text { Median: } \$ 59,153\end{array}$ & NREL Survey & \multirow{5}{*}{$\begin{array}{l}\text { Includes new } \\
\text { storage tank, pump, } \\
\text { dispenser(s), piping, } \\
\text { wiring, excavation, } \\
\text { and concrete work }\end{array}$} & \multirow{5}{*}{$\begin{array}{l}\text { Dispenser needs, excavation, } \\
\text { concrete work, sell backs, canopy } \\
\text { tank size, location, labor price, } \\
\text { regulations }\end{array}$} \\
\hline & $\$ 50,000-\$ 200,000$ & NACS & & \\
\hline & $\$ 50,000-\$ 70,000$ & DOT, EPA, DOE & & \\
\hline & $>\$ 50,000$ & NEVC & & \\
\hline & $<\$ 62,407$ & DAl & & \\
\hline \multirow{4}{*}{$\begin{array}{l}\text { Convert } \\
\text { existing tank, } \\
\text { new or retrofit } \\
\text { dispenser(s) }\end{array}$} & $\begin{array}{l}\text { Mean: } \$ 21,031 \\
\text { Median: } \$ 11,237\end{array}$ & NREL Survey & \multirow{4}{*}{$\begin{array}{l}\text { Tank cleaning, } \\
\text { replace non-compatible } \\
\text { components in piping } \\
\text { and dispensers }\end{array}$} & \multirow{4}{*}{$\begin{array}{l}\text { Dispenser needs, number of } \\
\text { non-compatible components, } \\
\text { location, labor price, regulations }\end{array}$} \\
\hline & $\$ 19,000-\$ 30,000$ & DAl & & \\
\hline & $\$ 5,000-\$ 30,000$ & DOT, EPA, DOE & & \\
\hline & $\$ 2,500-25,000$ & NEVC & & \\
\hline
\end{tabular}

*Full citations listed in "Sources of Literature Estimates." 
the type of ground (soil, rock, or mud) being excavated. Some stations have greatly reduced excavation costs by using above-ground storage tanks. Costs also largely depend on the amount of concrete work required. This can range from a new fueling island and driveway to a simple slab covering an underground storage tank. Other variables include:

- Sell backs. Tanks and dispensers can be sold on the second-hand market for a considerable price. This amount is subtracted from the total project cost.

- Canopy. Some projects include a new canopy-a large expense.

- Tank size. Larger tanks cost more.

- Location. Regions with many E85 stations tend to have lower costs due to increased experience and

\section{Sources of Literature Estimates}

DOT, DOE, and EPA. Report to Congress: Effects of the Alternative Motor Fuels Act CAFE Incentives Policy (2002).

DAl estimates in Reynolds, R., Ethanol's True Potential Contribution to U.S. Energy Security: Ethanol Demand Pull Study Analysis (2006). Work performed by DAI.

NREL, Johnson, Caley. E85 Business Case: When and Why to Sell E85, (2007).

Miller, Paul. EPA Office of Underground Storage Tanks. Interview (2007).

National Association of Convenience Store (NACS) estimates in Eichberger, J., and Scott, G., Letter to U.S. Congress Opposing Mandatory E85 Sales (2006).

National Ethanol Vehicle Coalition (NEVC) estimates provided by NEVC to its members and cited in a General Motors presentation (2006). competition of installation technicians. Regions (and urban areas) with more stringent regulations and permitting procedures have higher costs. Regions with high labor prices also have higher E85 project costs.

\section{Least Expensive Stations}

In the existing-tank category, the three stations with the lowest costs $(\$ 1,736, \$ 2,334$, and $\$ 2,547)$ took conversion shortcuts that are not recommended because of concerns about safety and materials. These shortcuts included failing to clean the tank before filling it with E85, declining to replace equipment components that may not be compatible with E85, and excluding signage costs.

\section{Future Costs}

Multiple issues could affect the costs of E85 stations in the future. The most prominent of these are:

- Increased experience and competition of installation technicians could lower the cost of new tank installations in more areas.

- Underwriters Laboratories' new fuel dispenser listing could increase the average cost of projects by guiding them away from unlisted dispenser retrofits toward purchasing new, certified dispensers.

- The declining number of opportunities to convert existing tanks could raise station costs by shifting E85 projects toward new tank configurations. The average new tank project costs $\$ 50,700$ more than the average tank conversion project. Since gasoline stations only have an average of 3.3 tanks in the United States (Miller, 2007), the number of tanks available for conversion is limited. Furthermore, sales of premium, diesel, or kerosene must be low to make the conversion of these tanks economically viable (Johnson, 2007).
National Renewable Energy Laboratory

1617 Cole Boulevard, Golden, Colorado 80401-3393 303-275-3000 • www.nrel.gov

NREL is a national laboratory of the U.S. Department of Energy

Office of Energy Efficiency and Renewable Energy

Operated by the Midwest Research Institute - Battelle
NREL/FS-540-42390

March 2008

This publication is subject to government rights.

Printed with a renewable-source ink on paper containing at least $50 \%$ wastepaper, including $10 \%$ post consumer waste. 